\title{
TIME-SERIES EVIDENCE OF THE EFFECT OF THE MINIMUM WAGE ON YOUTH EMPLOYMENT \\ AND UNEMPLOYMENT
}

\author{
Charles Brown \\ Curtis Gilroy \\ Andrew Kohen \\ Working Paper No. 790 \\ NATIONAL BUREAU OF ECONOMIC RESEARCH \\ 1050 Massachusetts Avenue \\ Cambridge MA 02138 \\ October 1981
}

\begin{abstract}
Charles Brown and Andrew Kohen are Associate Professors of Economics at the University of Maryland and James Madison University, respectively. Curtis Gilroy is a Senior Econornist with the Minimum Wage Study Conmission. The opinions expressed in this paper are those of the authors and do not necessarily reflect the official position of the institutions with which they are affiliated. We benefited from comments of Jacob Mincer and Finis Welch on an earlier version of the paper, and from the assistance of John Stinson in obtaining the data. Ann Levin and Nancy Zeitler provided helpful research assistance. The research reported here is part of the NBER's research program in Iabor Studies.
\end{abstract}


NBER Working Paper \#790

October 1981

Time Series Evidence of the Effect of the Minimum Wage

on Youth Employment and Unemployment

\section{ABSTRACT}

While previous time series studies have quite consistently found that the minimum wage reduces teenage employment, the extent of this reduction is much less certain. Moreover, because few previous studies report results of more than one specification, the causes of differences in estimated impacts are not well understood. Less consensus is evident on the effect of the minimum wage on teenage unemployment, or its relative impact on black and white teenagers.

The purpose of this paper is both to update earlier work and to analyze the sensitivity of estimated minimum wage effects to alternative specification choices. In addition to providing estimates of the effect of minimum wage increases on aggregate employment and unemployment rates of teenagers, we explore several related issues: the relative importance of changing the level and coverage of the minimum wage; the timing of responses to a change in the minimum; effects on part-time and full-time work; effects on young adults (age 20-24).

Charles Brown Department of Economics University of Maryland College Park, MD 20742 (301) $454-4182$
Curtis Gilroy U.S. Army Research Institute 5001 Eisenhower Avenue Alexandria, VA 22333

(202) $274-8104$
Andrew Kohen Department of Economics James Madison University Harrisonburg, VA 22807 (703) 433-6605 
In the last ten years, roughly twenty time-series studies of the effects of minimum wages on the employment and unemployment of teenagers (16- to 19-yearolds) have appeared. For teenagers as a group, most studies found that a 10 percent increase in the minimum wage would reduce teenage employment by one to three percent. The range of estimates of the effect of such an increase on the unemployment rate was considerably wider -- from essentially zero to over three percent (Brown, Gilroy and Kohen, 1981). Our survey revealed no support for the popular view that black teenagers suffer larger employment losses than their white counterparts, although there is some evidence that unemployment effects of the minimum wage are larger for blacks than for whites. The few studies which focused on 20-24 year olds found that the minimum wage reduced employment and increased unemployment for this group, but by lesser amounts than for teenagers.

In most of the research, the period studied ended in the late 1960s or early 1970s, so that the more recent experience (the 1974 and 1977 Amendments to the Fair Labor Standards Act) was not included. As one might expect, the studies differ in their choice of functional forms, lag structures, and independent variables. Surprisingly, however, there is very little discussion of how these differences affect the estimated minimum wage effects.

The purpose of this paper is to update existing estimates of the effects of minimum wages on employment and unemployment rates of youth, and to compare the results of different specifications. Section I briefly describes the theoretical framework in which the minimum wage has been analyzed. Section II discusses an operational model for the estimation of employment and unemployment effects of changes in the minimum wage and presents a summary of estimates of the major studies, while Section III describes the data sources and estimation procedures together with the results of our empirical analysis. Section IV provides some 
empirical extensions to the basic analysis. Section $V$ summarizes the major findings and provides concluding remarks.

\section{THEORETICAL FRAMEWORK}

The conventional neoclassical theory posits a decline in the level of employment in response to an increase in (or introduction of) a statutory minimum wage. At the above-equilibrium wage, employers respond to the higher cost of labor by using less of $i t$, and an excess supply of labor forms as fewer jos are rationed among more workers. Of course, the basis of comparison is what would otherwise have occurred; in a situation where employment was expanding, the minimum wage would simply limit the increase in employment.

Two alternatives to this conventional competitive model are possible: the familiar textbook example of a monopsonist who may actually hire more labor in response to a skillfully set minimum (Stigler, 1946), and the case of an employer who is "shocked" into increasing productivity when faced with a higher wage bill as a result of the minimum wage. 1 The validity of these models is difficult to assess directly however. To the extent that their predictions of the employment effect differ from that of the standard model, they can be tested with the same estimating equations. That is, only the researcher's prior expectation about the direction of the employment effect would differ. ${ }^{2}$

Recent theoretical work on the employment effects associated with the minimum wage has centered on two basic extensions of the standard competitive model: (1) the explicit inclusion of both the covered and uncovered sectors, and (2) a more careful treatment of the effects of the minimum wage on measured unemployment.

Recognizing the existence of two types of jobs -- those which are covered by the provisions of the Fair Labor Standards Act (FLSA) and those which are 
not -- a mandated minimum wage increase would be expected to reduce employment in the covered sector. Workers who are unable to find jobs in this sector are faced with several alternatives: (1) accept employment in the uncovered sector, perhaps while searching for covered employment; (2) remain unemployed with the hope of obtaining a job in the covered sector; or (3) withdraw from the labor force. To the extent that the first alternative is chosen, the wage in the uncovered sector would fall, and the resultant employment increase would help mitigate the employment loss in the covered sector. There is a possibility, too, that wages in the uncovered sector may actually rise, if workers in the uncovered sector choose to search for jobs in the covered sector at the higher FLSA-determined wage.

The net result depends upon the elasticities of demand for labor in the covered and uncovered sectors, the rate of withdrawal from the labor force, and the extent to which displaced workers in the covered sector remain unemployed in hopes of finding work there. The relative magnitudes of these several factors clearly is an empirical matter, and the net outcome of their interaction cannot be predicted by theory alone.

The second refinement of the basic model is a movement away from the view that workers displaced by the imposition of a (higher) minimum wage, together with those who may be attracted to the labor market to search for work at the higher wage, comprise the pool of unemployed. Because some of these persons become discouraged with job prospects and leave the labor force, they are excluded from the official unemployment count. Mincer (1976) has formally modelled this latter choice, assuming that those who are officially unemployed regard the probability of finding a covered job as more attractive than either uncovered sector employment or nonmarket alternatives. In this model, the possibility of searching for covered-sector work while remaining employed in an uncovered job is not considered. 


\section{PREVIOUS RESEARCH}

Time-series studies which attempt to estimate the effect of minimum wages on the labor force status of youth have relied upon single equation models of the type

$$
Y=f\left(M W, D, X_{1} \ldots X_{n}\right)
$$

where the dependent variable $Y$ is a measure of labor force status. Independent variables include $M W$ as a measure of the minimum wage, $D$ as a business cycle variable, and $x_{1} \ldots x_{n}$ which represent a host of other presumably exogenous explanatory factors.

To measure the "employment effect" of the minimum wage, the ratio of employment to population is used most often as the dependent variable. "Unemployment effects" are usually measured as the effect of the minimum wage on the proportion of the labor force (or of the population) unemployed. Unemployment equations were characteristic of the earlier studies; the more recent research has estimated the effects of the minimum wage on the employment-population and labor force-population ratios, and has derived the unemployment effects from these.

The key variable, minimum wage, has generally been measured by the ratio of the nominal legal minimum wage to average hourly earnings weighted by coverage, as devised by Kaitz (1970). Ratios of minimum wage rates to average hourly earnings were calculated for each industry, weighted by the proportion of workers covered. These were combined into an index in which the weight for each industry ratio is the number of persons employed in the industry as a proportion of total employment (Gavett, 1970). Specifically, the index takes the form

$$
\sum_{i} \frac{E_{i}}{E_{t}}\left[\left[\frac{M W_{i}}{\overline{A H E}_{i}} \cdot C_{i}\right]+\left[\frac{M W_{i}^{*}}{\overline{A H E}_{i}} \cdot C_{i}^{*}\right]\right]
$$


where

$$
\begin{aligned}
& E=\text { nonagricultural employment } \\
& M W=\text { basic minimum wage rate } \\
& \text { AHE }=\text { average hourly earnings of nonsupervisory workers } \\
& C \quad=\quad \begin{array}{l}
\text { proportion of nonsupervisory workers covered by the basic } \\
\text { minimum wage rate }
\end{array} \\
& M W^{*}=\text { minimum wage rate for newly covered workers } \\
& C^{*}=\begin{array}{l}
\text { proportion of nonsupervisory employees covered by the mini- } \\
i \quad=\text { major industry division }
\end{array} \\
& t \quad=\text { total private nonagricultural economy }
\end{aligned}
$$

Most studies which use this index use teenage employment ratios as weights.

This formulation allows the index to reflect changes in coverage as well as in the level of the minimum wage, and further, embodies the idea that the impact of a given minimum would be greater the higher is that minimum relative to market-determined wages. Most studies have incorporated Kaitz's measure or some variant of it in their regression equations, combining the coverage and level of the minimum in a single variable.

All studies incorporate a business cycle variable as a measure of the overall demand for labor, for which many proxies have been used. Additional variables often included are those to control for youth's participation in the armed forces and in employment and training programs, school enrollment, and potential labor supply. Most studies have included a time trend variable as well.

The findings of those studies which attempt to measure the employment/unemployment effects of a minimum wage on teenagers (16-19 years) are reported in Table 1. In order to enhance the comparability of these studies, their results are displayed in terms of elasticities for employment and percentage point 
increases for the unemployment rate. $^{3}$

To further enhance comparability of results, several types of aggregation 4 were necessary: (1) combining separate estimates for 16-17 and 18-19 year olds when estimates for the 16-19 group were not presented; (2) for different racesex groups when results for teenagers as a whole were not reported; and (3) separate estimates for enrolled and non-enrolled individuals. 5

The unemployment effects in Table 1 represent the change in the unemployment rate due to a 10 percent change in the minimum wage. For example, an entry of 0.50 would indicate that a minimum wage increase of 10 percent is estimated to raise the unemployment rate from, say, 6.0 to 6.5 percent. Just as the employment elasticities were aggregated as described above, so the labor force elasticities were similarly weighted using labor force shares.

On balance, the effects of a 10 percent increase in the minimum wage are estimated to result in about a 1-3 percent reduction in total teenage employment (Table 1). All studies find a negative employment effect for all teenagers together. Since it was necessary to compute many of the overall "effects" from the disaggregated age-sex-race equations, it is not possible to conduct tests to determine whether they are statistically significant. The coefficients from these disaggregated equations were mostly negative, with about half being statistically significant.

Although the research is consistent in finding some employment reduction associated with minimum wage increases, the estimated effects on unemployment appear to be considerably more varied. Of particular note are the diverse unemployment effects estimated by Adie (1971) and Moore (1971) on the one hand, and Lovell (1973) on the other in response to a 10 percent increase in the minimum wage.

Table 1 does demonstrate that there are many different specifications re- 
presented in these studies. Indeed, the only generalization one can make about all the studies is that each includes some measure of changing economic conditions as a control variable. It is difficult to assess how the differences in model specifications affect the results since most authors do not report how their findings changed as a result of changes in variables, functional form, etc. Lovell (1973) is an exception to this and he found that inclusion of one variable (youth's share of population) had important consequences for the estimated unemployment effects. Table 1 bears this out. Two of the four largest estimates appear in studies which exclude the population share variable (Adie, 1971 and 1973) while the four smaller estimates are found in studies which include it (Kaitz, 1970; Love11, 1972 and 1973; Freeman, 1979). 6

The issue of which "control" variables ought to be included in the estimating equations has not been fully resolved. There is general agreement that other determinants of demand for teenagers should be held constant in estimating the effect of the minimum wage on employment, labor force participation, and unemployment. There is less agreement not only on the appropriateness of including supply side variables (Adie-Gallaway, 1973; Fisher, 1973; Love11, 1973; Goldfarb, 1974), but on precisely which ones and the form they should take if included (Wachter-Kim, 1979).

The simple supply-demand model described above is sometimes used to argue for the exclusion of supply-determining variables from both employment and unemployment equations. The model suggests that employment is demand-determined in the presence of a minimum wage (i.e., how much excess supply is present has no effect on employment), so that supply-side variables do not belong in the estimating equation. Moreover, because supply would equal demand in the absence of the minimum wage, increases in the supply of teenagers which increase teenage unemployment are really "minimum wage" effects as well, and hence are mistakenly 
attributed to the supply-side variables if they are included in the estimation.

In our view, this position loses much of its persuasiveness once the overly restrictive assumptions of the simplest supply-demand model are relaxed. For example, the view that employment of teenagers is demand-determined may be correct for the half of teenagers who earn the minimum wage, but is hard to accept for the remaining half who earn more than the minimum. Their employment (and hence the employment of teenagers as a group) must depend on the relative supply as well as the demand for teenage labor. (Even if the demand-determination argument were correct, including truly exogenous supply-side variables would not bias the minimum wage coefficient in the employment equation, though they might somewhat reduce the precision with which it can be estimated.)?

Including supply-determining variables in equations explaining teenage unemployment also seems warranted. Contrary to the apparent message of the simplest supply-demand model, some teenagers would be unemployed in the absence of the minimum wage, as is demonstrated by the non-zero unemployment rate of teenagers who ordinarily earn more than the minimum. Hence, the extent of unemployment not caused by the minimum wage must be held constant, and including variables which reflect relative supplies is necessary. This does, perhaps, introduce some ambiguity into estimates of the effect of the minimum wage on teenage unemployment -- how much teenage unemployment would be reduced if the minimum wage were repealed. However, the relevant policy issue is the effect of marginal changes in the minimum wage, and holding the relative supply of teenagers constant is certainly necessary to make that evaluation. ${ }^{8}$

\section{RESULTS}

Like the studies listed in Table 1 , our basic sources of data were the published and unpublished monthly series from the Current Population Survey (CPS). 
As did nearly all of those studies, we used quarterly averages of the monthly observations. The variables we constructed from these data were:

EM/P: $\quad$ the ratio of civilian employment to civilian population, 9 for teenagers ( 16 to 19 years of age) $\begin{array}{ll}L F / P: & \text { the ratio of civilian labor force to civilian population, } \\ & \text { for teenagers }\end{array}$ UR: the ratio of civilian unemployment to civilian labor force,
for teenagers

YK: the "Kaitz" index discussed in Section II, using teenage
employment as weights 10

UPR: the ratio of civilian unemployment to civilian labor force, for males aged 25-54 AF/P: the ratio of teenagers in the armed forces to total teenage
population

EN/P: the ratio of teenagers enrolled in school to teenage civilian population, from the October supplement to the CPS. The October values were assigned to the fourth quarter of the survey year and the three following quarters in the next calendar year.

TR/P: $\quad$ the ratio of enrollments in federal training and employment programs of those aged 16-21 to civilian population aged 1621. The numerator was calculated from (sometimes incomplete) unpublished data for 19 separate programs; considerable estimating was involved. The denominator was approximated by the population 16-19 plus two-fifths of the population 20-24.

SY: the fraction of those aged 16-19 who are 16-17

POP: the ratio of teenage civilian population to total civilian population

POPA: the ratio of civilian population 20-24 to total civilian population

PCWEL: $\quad$ price-deflated "welfare" (Aid to Families with Dependent Children, Food Stamp, and Commodity Distribution programs) benefits per woman of child-bearing age (16-44)

T: a linear time trend

TSQ: $\quad T$ squared

$Q 2, Q 3, Q 4$ : dummy variables for the second, third and fourth quarters 


\section{Effects on Teenage Employment}

Table 2 presents our estimates of the effects of minimum wages on teenage employment, using various specifications of the estimating equation. The four columns reflect differences in the functional form of the equation -- linear or double-log -- and the estimation procedure -- GLS (which takes into account serial correlation in the disturbance terms) or OLS. Because the OLS Durbin-Watson (DW) statistics consistently showed appreciable serial correlation (a typical DW. statistic being 1.0 or less), the GLS equations should be given greater weight; the OLS equations are included in part because correction for serial correlation in the literature is rare. ${ }^{11}$ The rows of Table 2 differ in the control variables included in addition to the minimum wage index in explaining the employment/population ratio.

Line 1 of Table 2 reports estimates from our "basic" equation -- one which controls for season of the year, trend (as well as a quadratic time trend), cyclical factors (measured by the prime-age adult unemployment rate), and four supply-side variables ( $S Y, A F / P, T R / P$, and $P O P$ ), in addition to the minimum wage index $Y K$. The coefficients from these regressions have been converted to the same measure used in Table 1: the percent change in employment resulting from a 10 percent change in the minimum wage.

Apart from the "GLS linear" estimates, the versions of the "basic" equation imply a one percent reduction in teenage employment as a result of a 10 percent increase in the minimum wage index. The GLS linear estimate -- which uses the linear specification often found in the literature but which corrects for firstorder serial correlation -- is only about one half as large.

Lines 2-6 report results of individually deleting five variables which are often omitted from the studies in Table 1 -- the quadratic time-trend term, and the four supply-side variables. These alterations have relatively little effect 
on the estimates -- implying roughly one percent employment reductions in response to a 10 percent increase in the minimum wage index. Once again the GLS linear procedure produces consistently smaller estimates, but these estimates, too, are rather insensitive to the inclusion or exclusion of these "marginal" variables.

Lines 7-9 report the results of individually adding variables to the estimating equation. In line 7, POPA, the population share of young adults aged 20-24 is added. One would expect that young adults are relatively substitutable for teenagers, so that an increased availability of young adults would tend to reduce teenage employment. However, the estimated coefficient of POPA (not shown in Table 2) was consistently and significantly positive. In any case, its inclusion raises the estimated impact of the minimum wage by three to six tenths of a percentage point.

We also considered the possibility that expansions in welfare programs were an important determinant of teenage employment. Presumably, availability of we 1fare benefits wouid act as a deterrent to employment by welfare-eligible teenagers. We measured the impact of welfare programs (PCWEL) by the price-deflated value of benefits under the Aid to Families with Dependent Children, Food Stamp, and Commodity Distribution programs, per woman in the child-bearing years. An important methodological issue is whether to use a benefits per case (or per recipient) or a benefits per capita measure. We opted for the latter, on the grounds that much of the "welfare explosion" of the 1960s took the form of a greater fraction of eligible families receiving benefits -- a phenomenon which the benefits per capita measure captures, and the benefits per case (or per recipient) does not. Indeed, from 1967-73, the price-deflated value of AFDC benefits per case declined. In any event, increased real welfare benefits were associated with greater teenage employment, a result for which we have no ready 
explanation. Including the welfare variable raises the estimated effect of the minimum wage index by 0.6 point in the logarithmic equations, but has almost no effect in the linear versions. ${ }^{12}$

Finally, the enrollment/population ratio is added as a control variable (1ine 9). It was not included in the "basic" equation because of some misgivings about the possibility that it is determined by the minimum wage and/or the teenage employment or unemployment rates, and hence is not a pure "exogenous" variable. Its inclusion reduces the estimated minimum wage impact in the OLS equations, but has little effect in the GLS equations.

The minimum wage index $Y K$ used in lines 1-9 can be thought of as the product of the relative level of the minimum wage (compared with average hourly earnings) times the fraction of teenagers who are subject to minimum wage provisions. (This interpretation neglects the "weighted-average" nature of the variable.) While this seems a plausible way of combining relative level and coverage into a single index, it does not permit the estimation of the relative importance of changes in level and coverage alone, and may combine them incorectly (Fisher, 1973, p. 516; Gramlich, 1976, p. 434).

The logarithmic form of the equation is particularly convenient for relaxing the assumed strictly multiplicative constrained relationship between level and coverage. The logarithm of YK can be decomposed into the sum of the logarithms of relative level and coverage:

$$
\ln (Y K)=\ln (\text { minimum wage/average hourly earnings })+\ln (\text { coverage ratio })
$$

Our coverage variable is

$$
Y C=\sum_{i}\left(E_{i} / E\right)\left(C_{i}+C_{i}^{*}\right)
$$


The result of entering $\ln (Y C)$ in addition to $\ln (Y K)$ is shown in lines 10 and 11 . The effect of the relative minimum wage is then the coefficient of $\ln (Y K)$, while the effect of coverage is the coefficient of $\ln (Y K)$ plus the coefficient of $\ln (Y C)$. The t-statistic of $\ln (Y C)$ tests the hypothesis that the effects of $\ln (Y K)$ and $\ln (Y C)$ are equal -- i.e., that the restriction in the Kaitz index is correct. It can be seen that the estimated effect of the relative level of the minimum wage is about twice as large as in the constrained version (compare line 10 with line 1 , and line 11 with line 9). But the effect of a 10 percent change in coverage is much smaller than in the constrained version (e.g., in the GLS version of line 10 , coverage effect $=-1.76+1.41=-0.35$ compared with the constrained estimate [from line 1] of -0.89 ).

With the separate coverage variable included there are two hypotheses which can be tested: that coverage and level effects are equal, and that coverage effects are zero. Using the t-statistic for $\ln (Y C)$ to test the first hypothesis leads to its rejection (at the .01 level) only for the OLS equation in line 10. The t-statistic for the hypothesis that coverage does not matter (i.e., that the sum of the coeffcients of $\ln (Y K)$ and $\ln (Y C)$ are zero) can be calculated from the variance-covariance matrix of the estimated coefficients. Even the largest of the calculated t-statistics (1.41, for the OLS equation in line 10) is to small to reject the "no effect" hypothesis at conventional levels.

These results suggest a disturbing ambiguity in our conclusions regarding coverage and relative level effects. Like most other researchers (Moore, 1971; Love 11, 1973; Gramlich, 1976; Wachter-Kim, 1979; for contrary results, see Al-Salam, Quester and Welch, 1979), we find relatively weak coverage effects. This suggests that the relative level of the minimum wage is more important, and coverage less important, than intimated by the constrained equations which are typically estimated. However, we cannot reject the hypothes is that this 
result is due to chance alone; indeed we cannot estimate the importance of coverage with precision. ${ }^{13}$

The equations in Table 2 relate teenage employment to the current value of the minimum wage index, thus ignoring questions of the timing of responses to minimum wage increases. Several of the previous studies adopted distributed lag specifications for the minimum wage variable, thus assuming that the effects of a minimum wage increase occur gradually over time. As Welch ${ }^{14}$ has observed, however, the a priori case for a lagged response is debatable: High "normal" turnover rates among teenagers allow employers to achieve desired reductions in employment by refraining from hiring new people for a short period of time. Moreover, minimum wage increases are ordinarily announced in advance, so that responses could as easily precede as follow a new minimum.

Unlike earlier studies, which replaced YK with a distributed lag on YK, we included a (quadratic, unconstrained) distributed lag in addition to the current-quarter value, using the "basic" specification. With a 4-quarter lag, the sum of current and lagged effects were similar to the current-quarter estimates in Table 2, while an 8-quarter lag reduced this sum to essentially zero. Neither 4- or 8-quarter lags were statistically significant.

We also considered the pre-announcement issue by adding a dummy variable for periods when an increase in the minimum wage had been enacted but had not yet gone into effect. The YK coefficients were almost unaffected; the dummy variable reduced employment by 1 (GLS) to 2 (OLS) percent but was not significant in the GLS specifications. ${ }^{13}$. Adding lagged values of both YK and the dummy did not clarify matters: the results for YK were similar to those in the previous paragraph, while the current and lagged effects of the pre-announcement dummy were larger than in the current-quarter specification. Overall, we regard the pre-announcement effects as only suggestive; a theory of how firms should 
react to such announcements, and a "variable" which reflects that theory more carefully than our dummy variable, are clearly needed.

One experiment was conducted which did lead to unambiguous results. As was true of all studies in Table 1 , we neglected the impact of the student certification program in constructing our Kaitz index. To test the importance of this omission, we recomputed the Kaitz index by treating certified student employment as subject to a minimum wage of 85 percent of the basic minimum. The recomputed version of YK differed from the original version negligibly, and produced results almost identical (for the "basic" specification) to those in Table 2.

\section{Labor Force and Unemployment Rate Effects}

Estimates of the effect of a 10 percent increase on the teenage labor force (those employed or looking for work) are presented in Table 3. These are based on equations identical to those in Table 2, except that the labor force participation rate (LF/P) replaces the employment/population ratio (EM/P) as the dependent variable.

The results of the various specifications can be summarized quite succintly. In lines 1-9, where coverage and the level of the minimum are constrained to have similar effects, a 10 percent increase in the minimum leads to roughly a one percent reduction in the teenage labor force. In lines 10 and 11 , the effects of a 10 percent increase in the level of the minimum are somewhat larger ( 1.5 to 2 percent reduction), while coverage has a smaller effect ( 0.4 to 0.9 percent decrease). (Recall that, in lines 10 and 11 , the "coverage" effect is the sum of the $Y K$ and $Y C$ effects.) We found to our surprise, that this . withdrawal did not take the form of similar increases in the official "discouraged-worker" count (not shown in Table 3 ). 
If an increase in the minimum wage reduces employment and the labor force by the same percentage, as is suggested by Tables 2 and 4 , then the effect on unemployment would be zero. While the estimated effects on the teenage unemployment rate (Table 4) are not exactly zero, they are smaller than most reported in Table 1. To interpret Table 4, consider the last entry in line 1, which corresponds to a GLS estimate with a logarithmic estimating equation using the "basic" set of explanatory variables and the unemployment rate (or its logarithm) as the dependent variable. The 0.05 means that a 10 percent increase in the minimum wage is estimated to increase the teenage unemployment rate by .05 percentage point (e.g., from, say, 9.0 to 9.05 percent). Even the largest estimates suggest that a 10 percent increase in the minimum would increase teenage unemployment by only about one tenth of one percentage point. Caution is in order, however, in interpreting these unemployment effects. None of them is estimated with great precision, as reflected in the low t-statistics. Nevertheless, even taking a "high" estimate and going to the upper end of the 95 percent confidence interval, the estimates are still generally less than threetenths of a percentage point.

Most, though not a11, previous studies have found appreciable labor force withdrawa in response to increases in the minimum wage, so that many of those "disemployed" are not found among the "unemployed." The relative strength of the labor force withdrawal effect, however, is somewhat surprising, being essentially the same size (in percentage terms) as the employment effect. It should be noted, however, that several previous studies have obtained similar results (Kaitz, 1970; Love11, 1972 and 1973; Mattila, 1978; Freeman, 1979), and that our finding is quite robust in light of the specification experiments reported.

We also separated the sample into two subperiods -- 1954-69, roughly that 
used in the early studies in Table 1, and the reamining 1970-79 period. Results for the early subperiod looked very much like those in Table 2: employment and labor force effects of about one percent, and virtually no unemployment effect. In the later period, employment effects were somewhat larger (centering on -1.4 percent), labor force withdrawal smaller $(-0.6$ percent), and thus unemployment effects which were much larger ( 0.6 percentage points). These results broadly reinforce our earlier findings, except for the statistically significant unemployment effects in the recent period.

\section{EXTENSIONS OF THE BASIC ANALYSIS}

The purpose of this Section is to present additional time-series evidence on the effects of the minimum wage on employment and unemployment of young persons. Several refinements and extensions of the results in Section III are described below.

A. Estimated Effects of the Minimum Wage on Teenagers, by Race and Sex Many previous studies attempted to estimate employment and unemployment effects of the minimum wage on teenagers separately by race and sex. Indeed, in many cases the emphasis on these disaggregated results was so strong that no "adding up" of these results was provided to determine the effect on teenagers as a group. For the sake of comparison, this section presents our estimates of minimum wage effects on teenage labor force status stratified first by race and then by sex.

Table 5 contains estimates of the effects of a 10 percent increase in the minimum wage on the employment of white, nonwhite, male and female teenagers over the 1954-79 period. The first three lines are estimates derived from our "basic" specification. 16 
None of these variables is race- or sex-specific, apart from the fraction of teenagers who are 16-17.17 In general, the estimated effects for all whites, all males, and all females are similar to those estimated in Section III for teenagers as a whole -- a 10 percent increase in the minimum reducing teenage employment by roughly one percent. Effects for nonwhites are quite different; the point estimates suggesting that increases in the minimum wage actually increase their employment. However, none of the nonwhite effects are estimated with any precision. Estimates of the magnitude shown here could occur due to chance alone if the "true" effect were zero; moreover, we cannot reject the hypothesis that the white-nonwhite difference is due to chance alone. ${ }^{18}$

The third, sixth, and ninth lines of Table 5 present estimates of the effect of increases in the minimum wage on aggregate teenage employment, with the estimate calculated as a weighted average of the disaggregated results. The results were generally similar to the "directly-estimated" total effects, presented in Table 2, suggesting no systematic difference in the two ways of deriving aggregate estimates.

The effects of a 10 percent increase in the minimum wage on labor force participation and unemployment are also presented in Table 5. For whites, males and females, labor force participation declines in response to the minimum wage in about the same proportion that employment declines, so that unemployment rates are roughtly unaffected. Labor force participation by nonwhites also declines. Coupled with the estimated increase in their employment, this implies a decline in black unemployment in respose to the minimum wage. The labor force effects and the GLS estimates of the unemployment rate effects are not statistically significant, however. This suggests that, once again, the effects on nonwhites are not estimated with adequate precision with these data.

Welch (1976, pp. 121-122) has noted that population and labor force data 
for nonwhites are subject to considerable sampling error, due to the relatively small samples of nonwhite teenagers in the Current Population Survey (CPS). Since the size of the CPS sample has grown over time, weighting the observations by the estimated number of nonwhite teenagers actually surveyed seemed desirable. This would place greater weight on the more recent observations, which are presumably subject to smaller sampling errors. Having done this, we found the resulting estimates were only slightly closer to the white teenage results.

While it is often asserted that blacks are more adversely affected than whites by the minimum wage, previous studies offer quite mixed results on the issue. We find no support for the assertion, because of an inability to estimate accurately the effects on nonwhites. In any case, while we do not claim to have disproven the view that nonwhites are more adversely affected than whites, we would conclude that such an assertion must rest on theoretical rather than empirical grounds.

\section{B. Effects on Full-time Equivalent Employment}

As we have noted elsewhere (Brown, Gilroy and Kohen, 1981), most studies of employment effects of the minimum wage focus on the number of people employed, neglecting variations in hours worked per week by those who remain employed. The handful of studies which have examined the hours-of-work issue have produced conflicting results.

One way of addressing the hours-of-work issue is to consider the effect of the minimum wage on the fraction of those employed who work part time. An alternative approach, which is pursued here, is to convert part-time workers into full-time equivalent (FTE) employment. Assuming that the average part-time worker's workweek is roughly one-half that of the average full-time worker, FTE employment is defined as the number of full-time workers plus one-half that 
of part-time workers. We then estimated the effect of the minimum wage on FTE employment. If the minimum wage increases the fraction of those employed who are part-time workers, its (negative) effect on FTE employment should be larger than its effect on number of workers employed.

The findings are summarized in Table 6, which presents estimates based on the "basic" specification and that specfication with the enrollment/population ratio as an added independent variable. Since data on full-time and part-time employment of teenagers are available only since 1963, the FTE equations must be based on that shorter sample period. To keep the comparison between the standard number employed and FTE employment measures as exact as possible, we reestimated the previous employment equations based on the 1963-1979 sample period. Thus, line 1 of Table 6 reproduces the results of estimating the "basic" equation using the standard measure across the full (1954-79) sample. Line 2 presents the results of estimating the same equation on the shorter (1963-79) sample, and line 3 presents the estimated effect of the minimum wage on FTE employment over the 1963-79 period. Comparing lines 2 and 3, it is apparent that the effect of the minimum wage on FTE employment is somewhat larger than its effect on the standard employment measure. Lines 4-6 present analogous results, with the enrollment/population ratio also held constant. Again, the effects in line 6 are a bit larger than those in line 5. Overal1, Table 6 suggests that the effect of a 10 percent increase in the minimum wage is larger for FTE employment than for employment measured by number of workers. The difference is on the order of 0.4 percentage point, though the precise number is quite sensitive to the specification "choice."

More generally, we found that the estimates were quite sensitive to the choice of independent variables when a linear specification was used, but more robust for the logarithmic form. While precise numerical values are elusive, 
the direction of the results is not: the minimum wage increases the fraction of employed teenagers who work part time, so that FTE employment declines more than number of teenagers employed in response to an increase in the minimum wage.

C. Effects on Employment Status of Young Adults

All of the results presented thus far have been refinements of an analysis of the effects of the minimum wage on teenagers. While minimum-wage work is considerably less common among young adults aged 20-24 than among teenagers (about 15 percent of young adults worked at or below the minimum wage in 1980, compared with 45 percent of teenagers), one might still anticipate nontrivial effects on this "next-youngest" group.

In order to maximize comparability of results for young adults and teenagers, the estimated equations for employment/population ratios, labor force/ population ratios, and unemployment rates for young adults were as similar as possible to the earlier teenage equations. Apart from the obvious differences (EM/P, LF/P, UR, AF/P, EN/P and POP are based on young adult rather than teenage values), the only changes in these equations were:

(1) Because TR/P and $Y K$ are unavailable for young adults, $T R / P$ now refers to the fraction of all (labor-force age) persons in training programs, and TK and TC are the minimum wage index and coverage index using total employment to weight the individual-industry figures;

(2) The variable, SY, which reflected age composition within the teenage group, is deleted;

(3) In line 6 of Table 7, instead of adding the population share of young adults, the population share of teenagers (POPT) is added to the equation (because the population share of young adults is already included in the "basic" specification).

Estimates of the effect of a 10 percent increase in the minimum wage index 
on young adult employment are presented in Table 7. The "basic" equations all yield estimates of approximately 0.25 percent reduction in young-adult employment (roughly one fourth of the corresponding teenage impact). The estimates are generally not "significant" by conventional standards; i.e., such effects might occur due to chance alone. The remaining estimates in Table 7 center on the -0.25 estimate, but range from -.10 to -.60 . The relatively large standard errors of the coverage index, TC, in lines 9 and 10 suggest that it is no easier to disentangle coverage and level effects for young adults than it was for teenagers.

Estimated effects of a 10 percent increase on young adult labor force participation are also presented in Table 7. The "basic" equations suggest virtually no labor force withdrawal among young adults in response to the minimum wage; the other equations suggest both increases and reductions, but these are rarely more than 0.1 percent in either direction, and are never significant.

Reduced employment and little change in labor force participation imply increased unemployment in response to a minimum wage increase, and that is indeed what is displayed in Table 7. The "basic" specification suggests an increase in the young adult unemployment rate of 0.23 percent point (e.g., from 9.0 to 9.23 percent) in response to a 10 percent increase in the minimum wage. This estimate is reasonably precise, in that (1) the t-statistics suggest little likelihood that this result is due to chance alone, and (2) alternative specifications produce fairly similar estimates (with most in the 0.20 to 0.24 range).

Compared with the results for teenagers as a group in Section III, the employment effects are smaller (as we would expect due to the lower incidence of minimum wage workers among young adults). We do, however, find unemployment effects as well for young adults, which was not the case for teenagers. 


\section{CONCLUSION}

Previous empirical studies had estimated that a 10 percent increase in the minimum wage (or in the fraction of workers subject to it) would reduce teenage employment by one to three percent. Our own work, which uses a more up-to-date and longer sample period than most of these studies, suggests that one percent is a reasonable "single-number" estimate of the employment effect.

Our estimates clustered in a one half to one and one half percent range. The lowest numbers were based on GLS estimates and a linear relationship between teenage employment and the minimum wage index. The apparent sensitivity of the estimates to the OLS-GLS choice with the linear functional form is itself interesting; most previous studies report OLS estimates, while, in our data at least, serial correlation of the residuals is quite evident. The highest estimates come from double-logarithmic equations with the young adult population share or real welfare benefits added as explanatory variables. However, both of these variables were "wrong-signed" when added, so the revision in the minimum wage estimate they produce is debatable.

We also experimented with allowing the relative level and coverage of the minimum wage to have different effects on teenage employment. Like most previous studies which made similar attempts, we found "coverage" effects to be relatively weaker than "level" effects. However, the coverage effects were estimated with little precision, so the restriction that level and coverage have equal effects could not confidently be rejected. None of the previous studies had reported attempts to test that restriction.

We also explored the issue of the timing of responses to minimum wage increases. Previous studies had assumed either a same-quarter or a short fourthrough eight-quarter lagged response. None of the studies which included lagged variables discussed the effect of that choice. One might expect that 
omitting the lagged terms would lead to "missing" part of the minimum wage effect. However, no evidence was found to support that hypothesis. We did, however, find some evidence that part of the effect of an increase in the minimum wage is felt after the change is legislated but before it goes into effect. Earlier studies had generally found that teenagers, on balance, withdrew from the labor force in response to increases in the minimum wage. Our results are consistent with this response. Indeed, we found sufficient labor force withdrawal so that employment and labor force were reduced in near-equal proportions; as a result, the unemployment effects of the minimum wage were estimated to be practically zero. We find the importance of labor force withdrawal in our estimates surprisingly large (given our employment-effect estimates), but have no ready explanation for it. Our estimate compares with a zero to one percent estimate from most of the more recent studies, and a two to three percent estimate from earlier studies which had not incorporated the experience of the 1970s.

We did, however, find significant unemployment effects (of about 0.6 percentage point) when we considered only the most recent (1970-79) period. Since we had no a priori reason to expect differences between the 1970 s and the earlier period, we would not emphasize this result to the exclusion of the fullsample estimates.

In terms of the several refinements and extensions of the teenage results, we find little evidence that the effect of the minimum wage on the employment of white, male or female teens differed appreciably from the one percent estimate. Estimates for nonwhite teenagers are lower (indeed, the estimated effects were positive), but the standard errors of these estimates are large. A fair summary might be that effects seem to differ little by sex, but it is hard to say anything very definite about differences by race on the basis of the evi- 
dence presented. A similar conclusion would apply to estimated unemployment effects.

We also considered the effect of the minimum wage on full-time equivalent teenage employment and found that it declines somewhat more than the standard measure of numbers employed in response to the minimum, suggesting a movement from full-time toward part-time work in response to an increase in the minimum wage.

Finally, we examined the effect of a minimum wage increase on young adult (aged 20-24) labor force status. We found employment effects that tended to be negative - a 0.25 percent reduction in young adult employment in response to a 10 percent increase in the minimum -- though these estimates are often not statistically significant. One would have expected smaller effects for young adults than for teenagers, if only because fewer young adults are directly affected by changes in the minimum. We did find statistically significant unemployment effects (the increase in the minimum wage raising young adult unemployment rates by roughly 0.25 percentage points).

Overall, our results suggest a modest role for the minimum wage in explaining teenage labor market problems. A ten percent increase in the minimum wage will reduce teenage employment, probably by one percent. It may increase teenage unemployment, but certainly not by the two to three percentage points reported in some earlier papers on the subject. 


\section{NOTES}

1 Surveys of employers find reports of such responses from some (not all) firms, but there is no evidence on what fraction of increases in the minimum can be offset in this way. See U.S. Department of Labor (1959, pp. 28, 59, 107, 142, 206, 241-242) and Converse, et al. (1981, pp. 269-278).

2 In the only published avowed attempt to examine monopsony and shock effects empirically, West and McKee (1980) concluded that neither effect was demonstrable in the real world, at least in the extant literature.

${ }^{3}$ To measure employment effects, Table 1 presents the percent change in employment due to a 10 percent change in the minimum wage; i.e., 10 times the employment elasticity of the minimum wage $\eta(E)$. For studies which regressed the logarithm of an employment measure (the employment/population ratio [E/P], for example) on the logarithm of minimum wage $\left(w_{m}\right)$, the coefficient of the minimum wage variable is simply $n(E)$. For studies which use a linear rather than a double-logarithmic specification, $n(E)$ equals the regression coefficient times $\bar{W}_{m} /(\overline{E / P})$, where the bar indicates the mean value over the sample period.

The unemployment effects are the effect of a 10 percent change in the minimum wage on the unemployment rate. For the studies which estimate separate employment and labor force equations in logarithmic form using the employment/ population ratio $(E / P)$ and labor force participation rate $(L / P)$ as dependent variables, the minimum wage coefficients are the employment and labor force elasticities $n(E)$ and $n(L)$. Where the equations are linear, the regression coefficients must be multiplied by $\bar{W}_{m} /(\overline{E / P})$ and $\bar{W}_{m} /(\overline{L / P})$, respectively, to derive $\eta(E)$ and $\eta(L)$. The impact $(x)$ of a change in the minimum wage on the unemploy- 
ment rate can then be derived as follows:

$$
\begin{aligned}
& u=1-(E / L)=\text { the unemployment rate } \\
& \Delta u=-\left[\frac{L \Delta E-E \Delta L}{L^{2}}\right]=\frac{E}{L}\left[\frac{\Delta L}{L}-\frac{\Delta E}{E}\right]=(1-u)\left[\frac{\Delta L}{L}-\frac{\Delta E}{E}\right] \\
& \begin{aligned}
x=\frac{\Delta u}{\Delta W_{m} / W_{m}}=(1-u)(n(L)-n(E))= & \text { the impact on the unemployment rate } \\
& \text { (in percentage points) of a one } \\
& \text { percent change in the minimum wage. }
\end{aligned}
\end{aligned}
$$

Thus, if the minimum wage increased by 10 percent $\left(\Delta w_{m} / W_{m}=.10\right)$, u expressed as a decimal is .10x, and the change in the unemployment rate expressed as a percent is $10 x$. For studies in which the dependent variable is the unemployment rate expressed in percentage points, $x$ is calculated as the regression coefficient for the minimum wage multiplied by $\bar{w}_{\mathrm{m}}$.

${ }^{4}$ Some studies focused only on certain subsets of teenagers, and hence could not be included in Table 1. For a more detailed version of Table 1, see Brown, Gilroy and Kohen (1981).

${ }^{5}$ For any two groups, elasticities were aggregated according to the formula

$$
\eta\left(E_{1}+E_{2}\right)=\bar{S} \eta\left(E_{1}\right)+(1-\bar{S}) \eta\left(E_{2}\right) \quad \text { where } \bar{S}=E_{1} /\left(E_{1}+E_{2}\right)
$$

${ }^{6}$ The population share variable in the employment equations received less attention, although roughly half of the studies included it. On statistical grounds, one might expect larger (negative) minimum wage effects if this variable were omitted from an employment equation. The population share and minimum wage variables are apparently positively correlated, and the population share tends (when included) to have a negative effect on employment/population ratios.

${ }^{7}$ Note that virtually all of the studies in Table 1 estimate employment equations 
whose dependent variable is the employment-to-population ratio. Thus, even studies which appear not to introduce supply side variables in the list of independent variables have effectively included such factors in the dependent variable. If employment of teenagers is really demand determined, the proper dependent variable would be employment, not the employment-to-population ratio.

${ }^{8}$ The above argument might suggest an interaction of the minimum wage with relative teenage population in determining teenage unemployment. Given the difficulty in estimating even first-order effects precisely, the interactive approach has not been pursued. Note, however, that equations which use the logarithm of the unemployment rate as the dependent variable implicitly impose a multiplicative interaction between relative supply and the minimum wage.

${ }^{9}$ Data used in this study refer to the noninstitutional population.

${ }^{10}$ Data for the minimum wage and coverage components of the index were obtained from Minimum Wage and Maximum Hours and the Employment Standards Administration, U.S. Department of Labor. Industry employment and earnings are available from the BLS 790 survey of establishments published in Employment and Earnings, United States, 1909-1978 and Employment and Earnings Supplement. Because establishment payroll data do not contain information by age, the teenage weights were derived from CPS estimates.

$11 \mathrm{~A}$ first-order serial correlation correction is not exactly appropriate for the problem, even if the omitted factors which determine EM/P follow the appropriate pattern, because the rotation sequence in the Current Population Survey induces a rather complicated pattern of correlations between the sampling errors. House- 
holds selected for participation in the Current Population Survey are interviewed for four months, dropped from the survey for eight months, and then interviewed for an additional four months before leaving the sample permanently. Under this 4-8-4 rotation scheme, 75 percent of the sample in a given month is in the next month's sample, and 50 percent is surveyed in the same month a year later.

However, given the likelihood that the errors in our estimating equation are not due to sampling variation alone, the results of the correction for serial correlation are of interest. Because few of the previous studies have undertaken any such correction, the probability that their results could be due to chance alone may have been understated.

12 Betsey and Dunson (1981, Table 4) report broadly similar findings, using AFDC benefits per recipient to measure the effects of welfare programs.

${ }^{13}$ Gramlich has criticized the Kaitz index on different grounds, arguing that a simple theoretical model implies that the logarithm of employment should be a linear function of coverage times the logarithm of the relative minimum wage. Unfortunately, his "relative minimum wage" is the ratio of the minimum wage to the (unobserved) "equilibrium" wage, so that operationalizing his point is difficult. Indeed, Gramlich opts for dummy variables to reflect coverage, and reports little success in identifying coverage effects. While we share the concern on this issue, we have not been able to develop an alternative minimum wage "variable" which reflects his point. One version we considered was simply including coverage multiplied by the logarithm of the relative minimum wage as an explanatory variable. However, since the relative minimum is less than one, its logarithm is negative, so that coverage and level effects are constrained to have opposite effects. 
${ }^{14}$ In his comments on an earlier version of this paper, presented at the American Economic Association meetings, September 1980.

15 Boschen and Grossman (1981, p. 30) find that next year's minimum wage reduces teenage employment but next year's minimum wage coverage increases it. Both effects are "significant."

${ }^{16}$ The equations underlying Table 5 were also estimated with the (race- or sexspecific) enrollment/population ratio as an independent variable, and the results were very similar to those in Table 5 .

${ }^{17}$ Race- and sex-specific variables for the armed forces and training variables were unavailable; replacing the teenage population share with a race-specific share (as was done in several earlier studies) did not appreciably change the results.

${ }^{18}$ The standard error for the difference in minimum wage effects, $\sigma$, is given by

$$
\sigma^{2}=\sigma_{W}^{2}+\sigma_{N}^{2}-2 r \sigma_{W} \sigma_{N}
$$

where $\sigma_{W}$ and $\sigma_{N}$ are the standard errors for the white and nonwhite effects, and $r$ the correlation between the errors in these two effects. Moreover, $r$ is approximately equal to the correlation between the two equations' disturbances. (This would hold exactly if the independent variables in the white and nonwhite equations were identical; only SY differs by race.) The differences between white and nonwhite effects were not significant in the GLS equations ( 1.11 ( 1 inear) and 1.45 (logarithmic), though they were barely significant in the OLS equations (1.96 and 2.06$))$. 


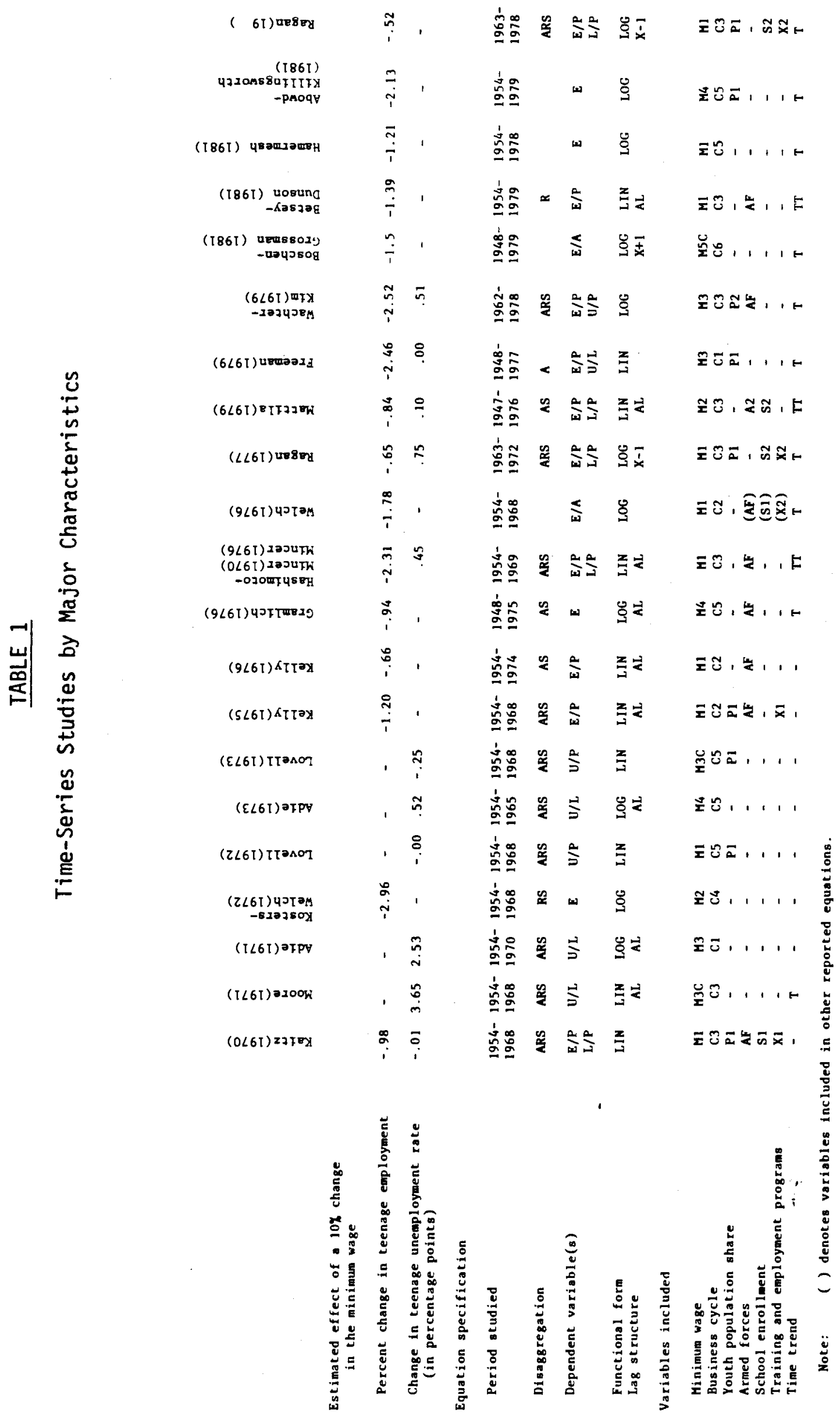


Key to Table 1

Disaggregation

$$
\begin{aligned}
& A=\text { age } \\
& R=\text { race } \\
& S=\text { sex }
\end{aligned}
$$

Dependent variables

$E=$ teenage employment

$U=$ teenage unemployment

$L=$ teenage labor force

$P=$ teenage population

$A=$ adult or total population

Functional forms

LIN = linear

$L O G=$ double logarithmic

Lag structure

$X-1=$ minimum wage lagged one period

$A L=A l m o n$ lag

$X+1=$ minimum wage in current period together with next year's value

Minimum wage variable

$M 1$ = youth coverage $\times$ minimum wage/average hourly wage

$M 2$ = total coverage $\times$ minimum wage/average hourly wage

$M 3=$ minimum wage/average hourly wage

M4 = minimum wage/price index

M5 = nominal minimum wage

$C=$ coverage as a separate variable

Business cycle

C1 = total unemployment rate

C2 = adult unemployment rate

C3 = prime-age male unemployment rate

C4 = total employment

$\mathrm{C5}=$ real output or output index

C6 $=$ money stock and its growth rate

Youth population share

$P 1=$ teenage population/total (or adult) population

P2 = youth $(16-24)$ population/total population

Armed forces

$$
\begin{aligned}
& A F=\text { armed forces/population (teenagers) } \\
& A 2=\text { separate equation for armed forces employment }
\end{aligned}
$$

School enrollment

SI = enrollment/population (teenagers)

S2 = separate equation for enrolled, not enrolled

Training and Employment Pograms

$X_{1}=$ dummy variables for years with substantial enrollments

$X_{2}=$ enrollment in specific programs/population

Time

$T=$ linear time trend

$T T$ = time and time squared 
TABLE 2

Estimated Effect of a 10 Percent Increase in the Minimum Wage on Teenage Employment (in percent)

\begin{tabular}{|c|c|c|c|c|c|c|}
\hline \multicolumn{2}{|c|}{ Specification } & \multirow{2}{*}{$\frac{\text { Effect of }}{Y K}$} & \multirow{2}{*}{$\begin{array}{l}\begin{array}{c}0 \mathrm{LS}^{1} \\
\text { Linear }\end{array} \\
\begin{array}{l}-1.02 \\
(3.08)\end{array}\end{array}$} & \multirow{2}{*}{$\begin{array}{c}\begin{array}{c}\text { GLS } \\
\text { Linear }\end{array} \\
-0.45 \\
(0.99)\end{array}$} & \multirow{2}{*}{$\begin{array}{c}\begin{array}{c}\text { OLS } \\
\text { Logarithmic }\end{array} \\
-1.06 \\
(3.25)\end{array}$} & \multirow{2}{*}{$\begin{array}{c}\begin{array}{c}\text { GLS }^{1} \\
\text { Logarithmic }\end{array} \\
-0.89 \\
(1.92)\end{array}$} \\
\hline 1. & Basic ${ }^{3}$ & & & & & \\
\hline 2. & Basic - TSQ & YK & $\begin{array}{l}-0.97 \\
(2.56)\end{array}$ & $\begin{array}{l}-0.48 \\
(1.01)\end{array}$ & $\begin{array}{l}-1.06 \\
(3.02)\end{array}$ & $\begin{array}{l}-0.93 \\
(1.99)\end{array}$ \\
\hline 3. & Basic - SY & YK & $\begin{array}{l}-0.72 \\
(1.91)\end{array}$ & $\begin{array}{l}-0.27 \\
(0.55)\end{array}$ & $\begin{array}{l}-0.79 \\
(2.16)\end{array}$ & $\begin{array}{l}-0.69 \\
(1.34)\end{array}$ \\
\hline 4. & Basic - AF/P & YK & $\begin{array}{l}-0.82 \\
(2.55)\end{array}$ & $\begin{array}{l}-0.36 \\
(0.79)\end{array}$ & $\begin{array}{l}-0.97 \\
(3.15)\end{array}$ & $\begin{array}{l}-0.84 \\
(1.87)\end{array}$ \\
\hline 5. & Basic - TR/P & YK & $\begin{array}{l}-1.02 \\
(3.10)\end{array}$ & $\begin{array}{l}-0.51 \\
(1.12)\end{array}$ & $\begin{array}{l}-1.06 \\
(3.25)\end{array}$ & $\begin{array}{l}-0.91 \\
(2.03)\end{array}$ \\
\hline 6. & Basic - POP & YK & $\begin{array}{l}-1.03 \\
(3.12)\end{array}$ & $\begin{array}{l}-0.44 \\
(0.96)\end{array}$ & $\begin{array}{l}-1.13 \\
(3.40)\end{array}$ & $\begin{array}{l}-0.84 \\
(1.80)\end{array}$ \\
\hline 7. & Basic + POPA & YK & $\begin{array}{l}-1.35 \\
(4.53)\end{array}$ & $\begin{array}{l}-0.77 \\
(1.82)\end{array}$ & $\begin{array}{l}-1.63 \\
(5.80)\end{array}$ & $\begin{array}{l}-1.41 \\
(3.82)\end{array}$ \\
\hline 8. & Basic + PCWEL & YK & $\begin{array}{l}-1.11 \\
(3.89)\end{array}$ & $\begin{array}{l}-0.66 \\
(1.59)\end{array}$ & $\begin{array}{l}-1.60 \\
(5.96)\end{array}$ & $\begin{array}{l}-1.47 \\
(4.34)\end{array}$ \\
\hline 9. & Basic + EN/P & YK & $\begin{array}{l}-0.75 \\
(2.10)\end{array}$ & $\begin{array}{l}-0.38 \\
(0.83)\end{array}$ & $\begin{array}{l}-0.83 \\
(2.51)\end{array}$ & $\begin{array}{l}-0.82 \\
(1.82)\end{array}$ \\
\hline 10. & Basic + YC & $\begin{array}{l}Y K \\
Y C\end{array}$ & & & $\begin{array}{l}-2.37 \\
(3.99) \\
1.84 \\
(2.60)\end{array}$ & $\begin{array}{l}-1.76 \\
(2.32) \\
1.41 \\
(1.40)\end{array}$ \\
\hline & Basic + YC + EN/P & $\begin{array}{l}Y K \\
Y C\end{array}$ & & & $\begin{array}{l}-1.85 \\
(2.86) \\
1.36 \\
(1.83)\end{array}$ & $\begin{array}{l}-1.50 \\
(1.98) \\
1.10 \\
(1.10)\end{array}$ \\
\hline
\end{tabular}

${ }^{1}$ OLS $=$ ordinary least squares $;$ GLS = generalized least squares (serial correlation correction by Cochrane-Orcott method).

2 In logarithmic equations, EM/P, UPR, POP, POPA, PCWEL, YK and $Y C$ are entered logarithmically, other variables linearly.

3"Basic" specification includes Q2, Q3, Q4, TIME, TSQ, UPR, SY, AF/P, TR/P, $P O P$, and $Y K$ as independent variables.

t-statistics in parentheses below coefficients. 
TABLE 3

Estimated Effect of a 10 Percent Increase in the Minimum Wage on Teenage Labor Force (in percent)

\begin{tabular}{|c|c|c|c|c|c|c|}
\hline \multicolumn{2}{|c|}{ Specification } & Effect of & \multirow{2}{*}{$\begin{array}{l}\begin{array}{c}0 \text { LS }^{1} \\
\text { Linear }\end{array} \\
-1.02 \\
(3.42)\end{array}$} & \multirow{2}{*}{$\begin{array}{l}\begin{array}{l}\mathrm{GLS}^{1} \\
\text { Linear }\end{array} \\
-0.99 \\
(2.39)\end{array}$} & \multirow{2}{*}{$\begin{array}{c}\begin{array}{c}\text { OLS } \\
\text { Logarithmic }^{2}\end{array} \\
\begin{array}{c}-1.01 \\
(3.10)\end{array}\end{array}$} & \multirow{2}{*}{$\begin{array}{c}\begin{array}{c}\text { GLS } \\
\text { Logari thmic }\end{array} \\
\frac{-1.28}{(2.82)}\end{array}$} \\
\hline 1. & Basic ${ }^{3}$ & YK & & & & \\
\hline 2. & Basic - TSQ & YK & $\begin{array}{l}-0.98 \\
(2.84)\end{array}$ & $\begin{array}{l}-1.04 \\
(2.34)\end{array}$ & $\begin{array}{l}-1.00 \\
(2.90)\end{array}$ & $\begin{array}{l}-1.35 \\
(2.92)\end{array}$ \\
\hline 3. & Basic - SY & YK & $\begin{array}{l}-0.82 \\
(2.54)\end{array}$ & $\begin{array}{l}-0.86 \\
(1.95)\end{array}$ & $\begin{array}{l}-0.80 \\
(2.32)\end{array}$ & $\begin{array}{l}-1.18 \\
(2.43)\end{array}$ \\
\hline 4. & Basic - AF/P & YK & $\begin{array}{l}-0.81 \\
(2.78)\end{array}$ & $\begin{array}{l}-0.81 \\
(1.96)\end{array}$ & $\begin{array}{l}-0.85 \\
(2.76)\end{array}$ & $\begin{array}{l}-1.12 \\
(2.55)\end{array}$ \\
\hline 5. & Basic - TR/P & YK & $\begin{array}{l}-1.03 \\
(3.45)\end{array}$ & $\begin{array}{l}-0.99 \\
(2.42)\end{array}$ & $\begin{array}{l}-1.00 \\
(3.10)\end{array}$ & $\begin{array}{l}-1.20 \\
(2.74)\end{array}$ \\
\hline 6. & Basic - POP & YK & $\begin{array}{l}-1.04 \\
(3.46)\end{array}$ & $\begin{array}{l}-0.98 \\
(2.37)\end{array}$ & $\begin{array}{l}-1.04 \\
(3.22)\end{array}$ & $\begin{array}{l}-1.27 \\
(2.77)\end{array}$ \\
\hline 7. & Basic + POPA & YK & $\begin{array}{l}-1.34 \\
(5.04)\end{array}$ & $\begin{array}{l}-1.25 \\
(3.53)\end{array}$ & $\begin{array}{l}-1.56 \\
(5.59)\end{array}$ & $\begin{array}{l}-1.58 \\
(4.51)\end{array}$ \\
\hline 8. & Basic + PCWEL & YK & $\begin{array}{l}-1.13 \\
(4.54)\end{array}$ & $\begin{array}{l}-1.12 \\
(3.51)\end{array}$ & $\begin{array}{l}-1.54 \\
(5.83)\end{array}$ & $\begin{array}{l}-1.61 \\
(5.06)\end{array}$ \\
\hline 9. & Basic + EN/P & YK & $\begin{array}{l}-0.67 \\
(2.09)\end{array}$ & $\begin{array}{l}-0.83 \\
(2.03)\end{array}$ & $\begin{array}{l}-0.74 \\
(2.30)\end{array}$ & $\begin{array}{l}-1.18 \\
(2.66)\end{array}$ \\
\hline 10. & Basic + YC & $\begin{array}{l}Y K \\
Y C\end{array}$ & & & $\begin{array}{l}-2.28 \\
(3.87) \\
1.79 \\
(2.56)\end{array}$ & $\begin{array}{l}-1.97 \\
(2.62) \\
1.14 \\
(1.17)\end{array}$ \\
\hline 11. & Basic $+Y C+E N / P$ & $\begin{array}{l}\text { YK } \\
\text { YC }\end{array}$ & & & $\begin{array}{l}-1.67 \\
(2.62) \\
1.23 \\
(1.68)\end{array}$ & $\begin{array}{c}-1.55 \\
(2.06) \\
0.64 \\
(0.65)\end{array}$ \\
\hline
\end{tabular}

See Notes to Table 2. 
TABLE 4

Estimated Effect of a 10 Percent Increase in the Minimum Wage on Teenage Unemployment Rates (in percentage points)

\begin{tabular}{|c|c|c|c|c|c|c|}
\hline \multicolumn{2}{|c|}{ Specification } & \multirow{2}{*}{$\frac{\text { Effect of }}{Y K}$} & \multirow{2}{*}{$\begin{array}{l}\text { OLS } \\
\text { Linear } \\
-0.02 \\
(0.12)\end{array}$} & \multirow{2}{*}{$\begin{array}{l}\text { GLS } \\
\text { Linear } \\
-0.03 \\
(0.23)\end{array}$} & \multirow{2}{*}{$\begin{array}{c}\text { OLS }^{1} \\
\text { Logarithmic } \\
0.05 \\
(0.45)\end{array}$} & \multirow{2}{*}{$\begin{array}{c}\text { GLS }^{1} \\
\text { Logarithmic } \\
0.05 \\
(0.44)\end{array}$} \\
\hline 1. & Basic ${ }^{3}$ & & & & & \\
\hline 2. & Basic - TSQ & YK & $\begin{array}{l}-0.02 \\
(0.15)\end{array}$ & $\begin{array}{l}-0.03 \\
(0.22)\end{array}$ & $\begin{array}{c}0.05 \\
(0.45)\end{array}$ & $\begin{array}{c}0.05 \\
(0.48)\end{array}$ \\
\hline 3. & Basic - SY & YK & $\begin{array}{l}-0.10 \\
(0.70)\end{array}$ & $\begin{array}{l}-0.14 \\
(0.96)\end{array}$ & $\begin{array}{l}-0.01 \\
(0.08)\end{array}$ & $\begin{array}{l}-0.03 \\
(0.28)\end{array}$ \\
\hline 4. & Basic - AF/P & YK & $\begin{array}{l}-0.01 \\
(0.09)\end{array}$ & $\begin{array}{l}-0.03 \\
(0.24)\end{array}$ & $\begin{array}{c}0.07 \\
(0.65)\end{array}$ & $\begin{array}{c}0.05 \\
(0.55)\end{array}$ \\
\hline 5. & Basic - TR/P & YK & $\begin{array}{l}-0.02 \\
(0.11)\end{array}$ & $\begin{array}{l}-0.03 \\
(0.25)\end{array}$ & $\begin{array}{c}0.05 \\
(0.46)\end{array}$ & $\begin{array}{c}0.04 \\
(0.42)\end{array}$ \\
\hline 6. & Basic - POP & YK & $\begin{array}{l}-0.01 \\
(0.09)\end{array}$ & $\begin{array}{l}-0.03 \\
(0.25)\end{array}$ & $\begin{array}{c}0.07 \\
(0.59)\end{array}$ & $\begin{array}{c}0.05 \\
(0.48)\end{array}$ \\
\hline 7. & Basic + POPA & YK & $\begin{array}{l}-0.02 \\
(0.14)\end{array}$ & $\begin{array}{l}-0.03 \\
(0.25)\end{array}$ & $\begin{array}{c}0.07 \\
(0.56)\end{array}$ & $\begin{array}{c}0.06 \\
(0.57)\end{array}$ \\
\hline 8. & Basic + PCWEL & YK & $\begin{array}{l}-0.02 \\
(0.16)\end{array}$ & $\begin{array}{l}-0.03 \\
(0.28)\end{array}$ & $\begin{array}{c}0.07 \\
(0.57)\end{array}$ & $\begin{array}{c}0.06 \\
(0.57)\end{array}$ \\
\hline 9. & Basic + EN/P & YK & $\begin{array}{c}0.07 \\
(0.51)\end{array}$ & $\begin{array}{c}0.06 \\
(0.44)\end{array}$ & $\begin{array}{c}0.07 \\
(0.62)\end{array}$ & $\begin{array}{c}0.06 \\
(0.59)\end{array}$ \\
\hline 10. & Basic + YC & $\begin{array}{l}\text { YK } \\
\text { YC }\end{array}$ & & & $\begin{array}{c}0.05 \\
(0.24) \\
0.00 \\
(0.00)\end{array}$ & $\begin{array}{c}0.04 \\
(0.22) \\
0.00 \\
(0.02)\end{array}$ \\
\hline 11. & Basic $+Y C+E N / P$ & $\begin{array}{l}\text { YK } \\
\text { YC }\end{array}$ & & & $\begin{array}{c}0.13 \\
(0.53) \\
-0.07 \\
(0.25)\end{array}$ & $\begin{array}{l}0.11 \\
(0.48) \\
-0.06 \\
(0.23)\end{array}$ \\
\hline
\end{tabular}

See Notes to Table 2. 


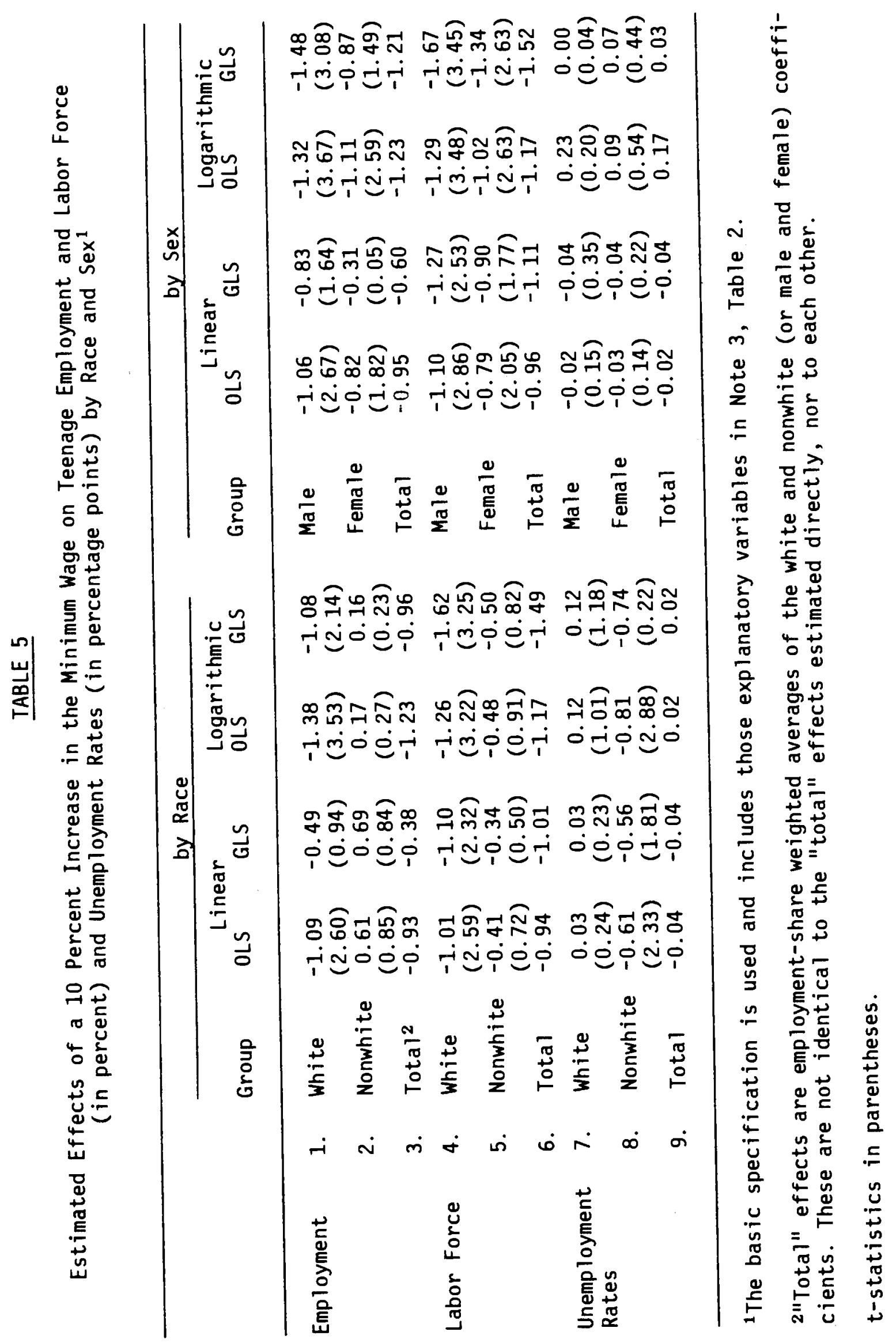




\section{TABLE 6}

Estimated Effects of a 10 Percent Increase in the Minimum Wage on Employment and Full-time Equivalent Employment of Teenagers (in percent)

\begin{tabular}{|c|c|c|c|c|c|c|}
\hline Specification & $\begin{array}{l}\text { Sample } \\
\text { Period }\end{array}$ & $\begin{array}{l}\text { Measure of } \\
\text { Employment }\end{array}$ & OLS & ${ }_{\text {GLS }}$ & $\begin{array}{l}\text { Logari } \\
\text { OLS }\end{array}$ & $\begin{array}{l}\text { hmic } \\
\text { GLS }\end{array}$ \\
\hline Basic 1 & $1954-79$ & $E M / P$ & $\begin{array}{l}-1.02 \\
(3.08)\end{array}$ & $\begin{array}{l}-0.45 \\
(0.99)\end{array}$ & $\begin{array}{l}-1.06 \\
(3.25)\end{array}$ & $\begin{array}{l}-0.89 \\
(1.92)\end{array}$ \\
\hline Basic ${ }^{1}$ & $1963-79$ & $E M / P$ & $\begin{array}{l}-1.42 \\
(3.29)\end{array}$ & $\begin{array}{l}-0.61 \\
(0.99)\end{array}$ & $\begin{array}{l}-1.74 \\
(3.73)\end{array}$ & $\begin{array}{l}-1.49 \\
(2.45)\end{array}$ \\
\hline Basic 1 & $1963-79$ & $\mathrm{FTE} / \mathrm{P}$ & $\begin{array}{l}-2.26 \\
(4.22)\end{array}$ & $\begin{array}{l}-0.82 \\
(1.09)\end{array}$ & $\begin{array}{l}-2.74 \\
(4.91)\end{array}$ & $\begin{array}{l}-2.08 \\
(2.85)\end{array}$ \\
\hline Basic + EN/P & $1954-79$ & $E M / P$ & $\begin{array}{l}-0.74 \\
(2.10)\end{array}$ & $\begin{array}{l}-0.38 \\
(0.83)\end{array}$ & $\begin{array}{l}-0.83 \\
(2.51)\end{array}$ & $\begin{array}{l}-0.82 \\
(1.82)\end{array}$ \\
\hline Basic + EN/P & $1963-79$ & $E M / P$ & $\begin{array}{l}-0.48 \\
(0.89)\end{array}$ & $\begin{array}{l}-0.21 \\
(0.33)\end{array}$ & $\begin{array}{l}-0.82 \\
(1.43)\end{array}$ & $\begin{array}{l}-0.69 \\
(1.05)\end{array}$ \\
\hline Basic + EN/P & $1963-79$ & $\mathrm{FTE} / \mathrm{P}$ & $\begin{array}{l}-0.94 \\
(1.43)\end{array}$ & $\begin{array}{l}-0.51 \\
(0.69)\end{array}$ & $\begin{array}{l}-1.38 \\
(2.36)\end{array}$ & $\begin{array}{l}-1.11 \\
(1.47)\end{array}$ \\
\hline
\end{tabular}

${ }^{1}$ See Note 3 , Table 2.

t-statistics in parentheses 


\section{TABLE 7}

Generalized Least Squares Estimates of the Effects of a 10 Percent Increase in the Minimum Wage on Young Adult Employment and Labor Force (in percent) and Unemployment Rates (in percentage points)

\begin{tabular}{|c|c|c|c|c|c|c|c|}
\hline \multicolumn{2}{|l|}{ Specification } & \multicolumn{2}{|c|}{$\begin{array}{c}\text { Employment } \\
\text { Linear Logarithmic }\end{array}$} & \multicolumn{2}{|c|}{$\begin{array}{c}\text { Labor Force } \\
\text { Linear Logarithmic }\end{array}$} & \multicolumn{2}{|c|}{$\begin{array}{l}\text { Unemployment Rates } \\
\text { Linear Logarithmic }\end{array}$} \\
\hline Basic ${ }^{1}$ & & $\begin{array}{l}-0.20 \\
(1.00)\end{array}$ & $\begin{array}{l}-0.26 \\
(1.58)\end{array}$ & $\begin{array}{c}0.06 \\
(0.34)\end{array}$ & $\begin{array}{l}-0.00 \\
(0.01)\end{array}$ & $\begin{array}{c}0.23 \\
(3.68)\end{array}$ & $\begin{array}{c}0.23 \\
(2.97)\end{array}$ \\
\hline Basic - TSQ & & $\begin{array}{l}-0.02 \\
(0.08)\end{array}$ & $\begin{array}{l}-0.11 \\
(0.40)\end{array}$ & $\begin{array}{c}0.22 \\
(0.99)\end{array}$ & $\begin{array}{c}0.13 \\
(0.57)\end{array}$ & $\begin{array}{c}0.23 \\
(3.79)\end{array}$ & $\begin{array}{c}0.23 \\
(3.06)\end{array}$ \\
\hline Basic - AF/P & & $\begin{array}{l}-0.31 \\
(1.49)\end{array}$ & $\begin{array}{l}-0.37 \\
(1.69)\end{array}$ & $\begin{array}{l}-0.10 \\
(0.49)\end{array}$ & $\begin{array}{l}-0.11 \\
(0.57)\end{array}$ & $\begin{array}{c}0.13 \\
(2.22)\end{array}$ & $\begin{array}{c}0.20 \\
(2.74)\end{array}$ \\
\hline Basic - TR/P & & $\begin{array}{l}-0.23 \\
(1.17)\end{array}$ & $\begin{array}{l}-0.28 \\
(1.69)\end{array}$ & $\begin{array}{c}0.02 \\
(0.09)\end{array}$ & $\begin{array}{l}-0.02 \\
(0.16)\end{array}$ & $\begin{array}{c}0.23 \\
(3.69)\end{array}$ & $\begin{array}{c}0.23 \\
(2.99)\end{array}$ \\
\hline Basic - POP & & $\begin{array}{l}-0.11 \\
(0.50)\end{array}$ & $\begin{array}{l}-0.22 \\
(1.29)\end{array}$ & $\begin{array}{c}0.07 \\
(0.40)\end{array}$ & $\begin{array}{l}-0.00 \\
(0.03)\end{array}$ & $\begin{array}{c}0.16 \\
(1.43)\end{array}$ & $\begin{array}{c}0.17 \\
(1.60)\end{array}$ \\
\hline Basic + POPT & & $\begin{array}{l}-0.30 \\
(1.25)\end{array}$ & $\begin{array}{l}-0.35 \\
(1.69)\end{array}$ & $\begin{array}{l}-0.03 \\
(0.15)\end{array}$ & $\begin{array}{l}-0.14 \\
(0.75)\end{array}$ & $\begin{array}{c}0.21 \\
(2.63)\end{array}$ & $\begin{array}{r}0.08 \\
(0.93\end{array}$ \\
\hline Basic + PCWEL & & $\begin{array}{l}-0.21 \\
(1.03)\end{array}$ & $\begin{array}{l}-0.26 \\
(1.59)\end{array}$ & $\begin{array}{c}0.08 \\
(0.44)\end{array}$ & $\begin{array}{c}0.01 \\
(0.08)\end{array}$ & $\begin{array}{c}0.23 \\
(3.72)\end{array}$ & $\begin{array}{c}0.23 \\
(2.98)\end{array}$ \\
\hline Basic + EN/P & & $\begin{array}{l}-0.16 \\
(0.78)\end{array}$ & $\begin{array}{l}-0.19 \\
(1.05)\end{array}$ & $\begin{array}{c}0.09 \\
(0.53)\end{array}$ & $\begin{array}{c}0.04 \\
(0.28)\end{array}$ & $\begin{array}{c}0.23 \\
(3.57)\end{array}$ & $\begin{array}{c}0.23 \\
(2.85)\end{array}$ \\
\hline Basic + TC & $\begin{array}{l}\text { TK } \\
\text { TC }\end{array}$ & & $\begin{array}{c}-0.37 \\
(1.62) \\
0.41 \\
(0.70)\end{array}$ & & $\begin{array}{c}-0.06 \\
(0.29) \\
0.24 \\
(0.43)\end{array}$ & & $\begin{array}{c}-0.14 \\
(1.38) \\
0.36 \\
(1.39)\end{array}$ \\
\hline Basic $+E N / P+T C$ & $\begin{array}{l}\text { TK } \\
T C\end{array}$ & & $\begin{array}{c}-0.21) \\
(0.89) \\
0.13 \\
(0.22)\end{array}$ & & $\begin{array}{c}0.02 \\
(0.10) \\
0.09 \\
(0.15)\end{array}$ & & $\begin{array}{c}0.13 \\
(1.14) \\
0.38 \\
(1.39)\end{array}$ \\
\hline
\end{tabular}

${ }^{1}$ The basic specification includes seasonal (quarter) dummies, linear and quadratic time trends, the prime-age male unemployment rate, the ratio of armed forces to population for young adults, the ratio of training enrollments (all ages) to population, the young adult/total population (aged 16 and over), and the minimum wage index TK. t-statistics in parentheses. 


\section{REFERENCES}

Abowd, John and Killingsworth, Mark. "Structural Models of Minimum Wage Effects: Analysis of Wage and Coverage Policies." Report of the Minimum Wage Study

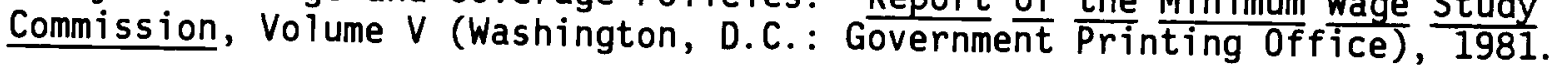

Adie, Douglas. "Teen-Age Unemployment and Real Federal Minimum Wages." Journal of Political Economy, March-April 1973.

. "The Lag in Effect of Minimum Wages on Teenage Unemployment." Proceedings of the Industrial Relations Research Association, 1971.

A]-Salam, Nabeel, Quester, Aline and Welch, Finis. "Some Determinants of the Level and Racial Composition of Teenage Employment." In S. Rottenberg, ed. , The Economics of Legal Minimum Wages (Washington, D.C.: American Enterprise Institute for Pub $\overline{1 i c ~ P o l} ; \overline{c y}$ Research), 1981.

Betsey, Charles L. and Dunson, Bruce. "Federal Minimum Wage Laws and the Employment of Minority Youth. " American Economic Review (Proceedings), May
1981.

Boschen, John and Grossman, Herschel. "The Federal Minimum Wage, Inflation, and Employment." NBER Working Paper No. 652, Apri1 1981.

Brown, Charles, Gilroy, Curtis, and Kohen, Andrew. "Effect of the Minimum Wage on Youth Employment and Unemployment. "Report of the Minimum Wage Study

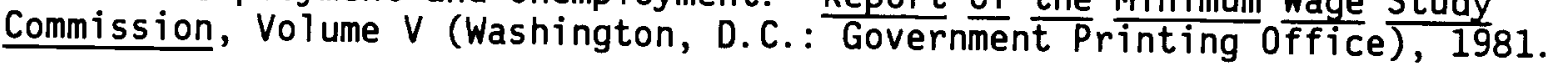

Converse, Murie1, et al. "The Minimum Wage: An Employer Survey." Report of the Minimum Wage Study Commission, Volume VI (Washington, D.C.: Government Printing Office), 1981.

Freeman, Richard. "Economic Determinants of Geographic and Individual Variation in the Labor Market Position of Young Persons." Presented at NBER Conference on Youth Unemployment, March 1979. Forthcoming in R. Freeman and D. Wise, eds., Youth Unemployment: Its Nature, Causes, and Consequences.

Gavett, Thomas. Introduction to Youth Unemployment and Minimum Wages. Bulletin 1657, U.S. Department of Labor, Bureau of Labor Statistics, 1970.

Gramlich, Edward. "Impact of Minimum Wages on Other Wages, Employment and Family Incomes." Brookings Papers on Economic Activity 2, 1976.

Hamermesh, Daniel S. "Minimum Wages and the Demand for Labor." NBER Working Paper No. 656, April 1981.

Hashimoto, Masanori and Mincer, Jacob. "Employment and Unemployment Effects of Minimum Wages." Unpublished paper. National Bureau of Economic Research, 1970.

Kaitz, Hyman. "Experience of the Past: The National Minimum." In Youth Unemployment and Minimum Wages. Bulletin 1657, U.S. Department of Labor, Bureau of Labor Statistics, 1970. 
Keliy, Terence. "Youth Employment Opportunities and the Minimum Wage: An Econometric Model of Occupational Choice." Unpublished paper, The Urban Institute, 1975.

"Two Policy Questions Regarding the Minimum Wage." Unpublished paper, The Urban Institute, 1976.

Love11, Michae1. "The Minimum Wage, Teenage Unemployment, and the Business Cycle." Western Economic Journal, December 1972.

December 1973.

"The Minimum Wage Reconsidered." Western Economic Journal,

Mattila, J. Peter. "Youth Labor Markets, Enrollments, and Minimum Wages." Proceedings of the Industrial Relations Research Association, 1978.

. "The Impact of Minimum Wages on Teenage Schooling and on the Part-time/Fuil-time Employment of Youth." In S. Rottenberg, ed., The Economics of Legal Minimum Wages (Washington, D.C.: American Enterprise Institute for Public Policy Research), 1981.

Mincer, Jacob. "Unemployment Effects of Minimum Wages." Journal of Political Economy, August 1976.

Moore, Thomas. "The Effect of Minimum Wages on Teenage Unemployment Rates." Journal of Political Economy, July-August 1971.

Ragan, James. "Minimum Wages and the Youth Labor Market." Review of Economics and Statistics, May 1977.

. "The Effect of a Legal Minimum Wage on the Pay and Employment of Teenage Students and Nonstudents. "In S. Rottenberg, ed., The Economics of Legal Minimum Wages (Washington, D.C.: American Enterprise Institute for Public Policy Research), 1981.

U.S. Department of Labor, Bureau of Labor Statistics. Employment and Earnings, United States, 1909-1978 (Washington, D.C.: Government Printing Office), 1979.

, Bureau of Labor Statistics. Employment and Earnings Supplement, Revised Establishment Data (Washington, D.C.: Government Printing Office), 1979 .

- Employment Standards Administration. Minimum Wage and Maximum Hours Standards Under the Fair Labor Standards Act (Washington, D.C.: Government Printing Office), various issues.

, Wage and Hour and Public Contracts Division. Studies of the Economic Effects of the $\$ 1$ Minimum Wage, Part II: Effects in Selected Low-Wage Industries and Localities, January 1959.

Wachter, Michael and Kim, C. "Time Series Changes in Youth Joblessness." Presented at NBER Conference on Youth Unemployment, May 1979. Forthcoming in R. Freeman and D. Wise, eds., Youth Unemployment: Its Nature, Causes, and Consequences. 
Welch, Finis. "Minimum Wage Legislation in the United States." In Orley Ashenfelter and James Blum, eds., Evaluating the Labor Market Effects of Social Programs, Princeton University Press, Special Report Series, No. $\frac{1}{120} \frac{1976 .}{1976}$

. "Minimum Wage Legislation in the United States." Economic Inquiry, September 1974.

. "Minimum Wage Legislation in the United States: Reply." Economic Inquiry, January 1977.

West, E.G. and McKee, Michae 1. "Monopsony and 'Shock' Arguments for Minimum Wages." Southern Economic Journal, January 1980. 